\title{
WANITA KARIR DALAM PRESPEKTIF PSIKOLOGIS DAN SOSIOLOGIS KELUARGA SERTA HUKUM ISLAM
}

\section{Afif Muamar}

Fakultas Syariah dan Ekonomi Islam

IAIN Syekh Nurjati afifmuamar85@gmail.com

- Received: 03 April 2019 •Accepted: 05 Juli 2019 •Published online: 30 Agustus 2019

\begin{abstract}
The problem of career women does not only concern the normative aspects of Islamic teachings, but their existence also touches on the psychological and sociological aspects of the family. Therefore, this study has three objectives, namely first, to find out the psychological impact of career women in marriage and family. Secondly, knowing Islamic law about the activities of career women in the public domain. And third, knowing the reasons for allowing women to move in public areas. Using the method of library research, this study concludes that, first, psychologically, the existence of a career woman can influence the marital and family arrangements, which if not properly regulated is not impossible that will result in disharmony between marriage and family. Secondly, in Islam, no one has the right to forbid women to work outside the home, even though their husbands. This is related to the Islamic doctrine itself which never distinguishes between men and women in terms of gender. Third, the concept of a career woman does not mean a wife/mother is free to work abandoning the fate of her marriage and family.
\end{abstract}

Keywords: Career Women, Psychological Family, Sociological Family and Islamic Law.

Abstrak: Persoalan wanita karir sebenarnya tidak hanya menyangkut aspek normatif ajaran Islam semata, namun keberadaannya juga menyentuh aspek psikologis dan sosiologis keluarga. Oleh karena itu, penelitian ini memiliki tiga tujuan, yaitu pertama, mengetahui dampak psikologis wanita karir dalam perkawinan dan keluarga. Kedua, mengetahui hukum Islam tentang aktivitas wanita karir di wilayah publik. Dan ketiga, mengetahui alasan diperbolehkannya wanita beraktivitas di wilayah publik. Dengan menggunakan metode penelitian kepustakaan, penelitian ini menyimpulkan bahwa, pertama, secara psikologis, keberadaan wanita karir bisa mempengaruhi tatanan perkawinan dan keluarga, yang apabila tidak diatur dengan baik bukan mustahil akan berakibat pada disharmonisasi perkawinan dan keluarga. Kedua, dalam Islam tidak ada yang berhak melarang wanita untuk bekerja di luar rumah, termasuk suami sekalipun. Hal ini terkait dengan doktrin Islam sendiri yang sebenarnya tidak pernah membedakan antara laki-laki dan perempuan dari sisi jenis kelamin. Ketiga, konsep wanita karir tidak berarti seorang isteri/ibu bebas bekerja menelantarkan nasib perkawinan dan keluarganya.

Kata Kunci: Wanita Karir, Psikologis Keluarga, Sosiologis keluarga dan Hukum Islam. 


\section{A. PENDAHULUAN}

Diskursus wanita karir dan keikutsertaannya dalam berbagai aktivitas publik adalah isu yang hingga kini masih diperdebatkan. Sebagian orang berpendapat, wanita dapat memperoleh apresiasi akan jati dirinya dengan bekerja dan aktif di sektor kehidupan luar rumah tangga. Bagi mereka, terjunnya wanita ke dunia karir bermakna positif, tidak saja bagi wanita sendiri, melainkan juga bagi keluarganya. Sementara sebagian yang lain menilai keikutsertaan wanita dalam beragam aktivitas publik, termasuk meniti karir di luar rumah tangga, adalahi sesuatu yang negatif. Bagi mereka, wanita yang bekerja di luar sektor domestik dapat merendahkan martabat wanita dan melalaikan tugas-tugas yang seharusnya diembannya, yaitu tugas kerumahtanggaan. Lebih lanjut menurut Herien Puspitawati, ${ }^{1}$ bahwa semua persoalan kesenjangan/ketimpangan gender berawal dari persepsi terhadap peran gender yang bias karena dibentuk oleh budaya yang secara turun-temurun dan sudah terinternalisasi sejak berabad-abad. Oleh karena itu, tidak jarang muncul anggapan bahwa wanita sebagai mahluk domestik yang tidak boleh berkecimpung dalam urusan publik. Seringkali, kedua pandangan yang bersebrangan itu-pro maupun kontra-didasarkan didasarkan atas dalil atau tafsir agama. ${ }^{2}$

Bagi kelompok yang mengapresiasi wanita bisa bekerja di sektor publik meyakini bahwa Islam adalah "agama ramah perempuan.” Islam adalah agama yang bertujuan untuk mewujudkan persaudaraan universal (universal brotherhood), kesetaraan (equality) dan keadilan sosial (social justice). ${ }^{3}$ Al-Qur'an sebagai rujukan utama umat Islam dipandang berprinsip melawan segala bentuk ketidakadilan, termasuk eksploitasi ekonomi, penindasan politik, dominasi budaya, dominasi gender, dan segala bentuk disequilibrium dan apertheit. ${ }^{4}$ Karena itu, keikutsertaan wanita dalam sektor publik seperti tampak dalam wanita karir, tidak melanggar ajaran Islam bahkan bagian dari ajaran Islam itu sendiri.

Sementara bagi kelompok yang tidak mau mengapresiasi keikutsertaan wanita dalam aktivitas publik, termasuk dalam soal wanita karir melandaskan argumentasinya pada sisi normatif Islam yang menurut mereka secara tegas membatasi ruang gerak

${ }^{1}$ Herien Puspitawati, "Persepsi Peran Gender terhadap Pekerjaan Domestik dan Publik Pada Mahasiswa IPB”, Yin Yang: Jurnal Studi Gender dan Anak, Vol. 5, No. 1 (Juni, 2010): 18.

${ }^{2}$ Masdar F. Mas'ud, Islam dan Hak Reproduksi Perempuan (Bandung: Mizan, 1997), 74.

${ }^{3}$ Asghar Ali Engineer, Islam dan Teologi Pembebasan, terj. Agung prihantoro, cet. ke-1 (Yogyakarta: Pustaka Pelajar, 1999), 33.

${ }^{4}$ Mansour Fakih, "Fiqh Sebagai Paradigma Keadilan," dalam Noor Ahmad, et.al., Epistemologi Syara': Mencari Format Baru Fiqh Indonesia, cet. ke-1 (Yogyakarta: Pustaka Pelajar, 2000), 143. 


\section{Afif Muamar}

perempuan hanya sebatas wilayah domestic, itupun dengan pola hirarkis, di mana perempuan ditempatkan sebagai mahluk kedua di bawah laki-laki. Dalam hal ini sering diungkapkan sejumlah ayat tentang penciptaan Hawa. Kepemimpinan laki-laki atas perempuan, poligami, hak-hak unilateral kaum laki-laki untuk bercerai, hak-hak kewarisan dan otoritas kesaksian hukum laki-laki yang lebih besar, tampak secara langsung memarginalkan perempuan, juga sejumlah hadis misoginis, ${ }^{5}$ seperti; hadis tentang pelarangan menyerahkan urusan pada kaum perempuan, hadis yang menyatakan bahwa keledai, anjing dan perempuan dapat membatalkan shalat, hadis tentang sujud kepada suami, serta kitab-kitab klasik yang menggambarkan perempuan sebagai separuh harga laki-laki, objek, dan sebagai mahluk domestik. ${ }^{6}$ Dari sejumlah teks ini, mereka meyakini perempuan sebagai mahluk domestik yang tidak berhak berpartisipasi di sektor publik, bahkan keluar rumah pun harus seizin suami.

Lepas dari perdebatan di atas, persoalan wanita karir sebenarnya tidak hanya menyangkut aspek normatif ajaran Islam—apakah boleh atau tidak boleh- lebih dari itu, adanya wanita karir juga menyentuh aspek psikologis dan sosiologis keluarga. Misalnya, wanita yang bekerja di luar rumah seringkali harus menanggung beban ganda, di samping harus mengurusi urusan rumah tangga dan keluarga, juga mesti bertanggung jawab pada pekerjaannya. Belum lagi persoalan yang secara psikologis dialami suami dan anak ketika isteri harus bekerja dan banyak menghabiskan waktu di luar rumah, tidak mustahil perkawinan dan keluarga menjadi tidak stabil lagi.

Dari sini menjadi jelas bahwa persoalan wanita karir bukan persoalan sederhana. Selain terkait dengan kesetaraan antara laki-laki dan perempuan, persoalan wanita karir juga berhubungan dengan terciptanya tujuan perkawinan dan konstruksi keluarga yang terbangun. Karena itu, pertanyaan pokoknya sekarang adalah pertama, bagaimana dampak secara psikologis bagi wanita karir bagi perkawinan dan keluarga? Kedua, apakah dalam Islam wanita diperbolehkan beraktivitas di wilayah publik sebagai wanita karir? Dan ketiga, bagaimana alasannya wanita diperbolehkan diperbolehkan beraktivitas di wilayah publik?

\footnotetext{
${ }^{5}$ Hadis Misoginis ialah hadis yang isinya membenci kaum perempuan. Istilah ini dipakai Fatima Mernissi untuk menyebut hadis-hadis yang melecehkan kaum perempuan. Lihat Fatima Mernissi, Wanita di dalam Islam, terj. Yaziar Radianti (Bandung: Pustaka, 1994), 62.

6 Masdar F. Mas'udi, "Perempuan diantara Lembaran Kitab Kuning," dalam Mansour Fakih, et.al., Membincang feminisme, 167-176.
} 


\section{B. METODOLOGI}

Jenis penelitian yang digunakan adalah penelitian kepustakaan. Penelitian kepustakaan merupakan penelitian yang penemuanya didapatkan dengan mencari data dari berbagai literatur dan referensi yang berhubungan dengan materi pembahasan. ${ }^{7}$ Oleh karena itu, penelitian tentang wanita karir dalam prespektif Islam dalam penilitian ini menggunakan tinjauan gender melalui metode review dokumen dan trend analysis.

Pendekatan penelitian yang dilakukan menggunakan pendekatan kualitatif normatif, yaitu sebagaimana cara yang digunakan dalam penelitian hukum yang dilakukan dengan cara meneliti bahan pustaka yang ada. ${ }^{8}$

Teknik pengumpulan data merupakan langkah yang paling strategis dalam penelitian, karena tujuan utama dari penelitian adalah mendapatkan data. ${ }^{9}$ Peneliti melakukan teknik pengumpulan data dengan melakukan penelitian terhadap berbagai literatur yang dilakukan untuk mencari konsep yang ada relevansinya dengan topik pembahasan melalui pengkajian buku-buku, jurnal, majalah, serta pendapat para ahli secara tidak langsung, yang kemudian akan dianalisis secara mendalam. Selain itu, penelitian ini menggunakan teknis analisis deskriptif, yaitu analisis dengan cara memaparkan data yang telah terkumpul dan tersusun secara sistematis. ${ }^{10}$

Sumber diperoleh dari dokumen dan informasi beberapa temuan-temuan di berbagai jurnal dan hasil penelitian sebelumnya. Dokumen tersebut telah melalui tahapan-tahapan analisis dari berbagai keabsahan data atau sumber yang banyak dikaji oleh para peneliti, serta dianalisis dengan fakta bersifat obyektif melihat perkembangan isu seputar wanita karir.

\section{HASIL DAN PEMBAHASAN}

\section{Definisi Wanita Karir}

Secara etimologis, wanita karir adalah gabungan dari dua kata, yaitu "wanita" dan "karir". Kata“wanita" berarti perempuan dewasa. Sementara "karir" memiliki dua pengertian, yaitu: pertama, perkembangan dan kemajuan dalam kehidupan, pekerjaan dan jabatan. Kedua, pekerjaan yang memberikan harapan untuk maju. ${ }^{11}$ Kata "karir"

\footnotetext{
${ }^{7}$ Moh. Nazir, Metode Penelitian (Bandung: Ghalia Indonesia, 2003), 193.

${ }^{8}$ Suerjono Sukanto dan Sri Mamudji, Penelitian Hukum Normatif Suatu Tinjauan Singkat, Cet. 11 (Jakarta: PT. Raja Grafindo Persada, 2009), 13-14.

${ }^{9}$ Sugiyono, Metode Penelitian Kuantitatif, Kualitatif Dan R\&D (Bandung: Alfabeta, 2013), 224.

${ }^{10}$ Jalaludin Rahmat, Metodologi Hukum (Jakarta: Fajar Agung, 1997), 134.

11 Anton M. Muleono, Kamus Besar Bahasa Indonesia, cet. II (Jakarta: Departemen Pendidikan dan Kebudayaan, 1989), 1007.
} 
sendiri sering dihubungkan dengan tingkat jenis atau pekerjaan seseorang. Misalnya, wanita karir bisa dikatakan sebagai wanita yang bergulat dalam kegiatan profesi (usaha dan perusahaan).12 Dari sini bisa dirumuskan bahwa konsep wanita karir meliputi; pertama, wanita yang aktif melakukan kegiatan-kegiatan untuk mencapai suatu kemajuan. Kedua, kegiatan itu berupa kegiatan professional sesuai bidang yang ditekuninya. Ketiga, bidang pekerjaan itu dapat mendatangkan kemajuan. Sehingga bisa dikatakan bahwa wanita karir merupakan wanita yang menekuni satu atau beberapa bidang pekerjaan berdasarkan keahlian tertentu yang dimilikinya untuk mencapai kemajuan dalam hidup, pekerjaan, atau jabatan. Beberapa istilah yang sering diidentikan dengan "wanita karir," yaitu: wanita bekerja dan Tenaga Kerja Wanita (TKW). ${ }^{13}$

Pembahasan “wanita karir' sendiri menekankan pada kata "karir". Meski dalam banyak hal wanita karir sering diidentikan dengan masalah financial, tapi sebenarnya financial bukanlah tujuan satu-satunya. Artinya, "Karir" tidak selalu bermakna uang, melainkan juga dikonotasikan sebagai tangga, hierarki dan struktur organisasi, yang melibatkan perencanaan matang dan memungkinkan bagi seseorang untuk meningkatkan posisi atau jabatan di lingkungan kerjanya. ${ }^{14}$ Dengan demikian, tidak semua wanita yang bekerja di luar rumah dapat diklaim sebagai wanita karir. Karir adalah profesi yang ditekuni secara serius untuk mencapai status setinggi-tingginya dalam hierarkhi organisasi di lingkungan kerja. Dalam karir, keberhasilan kerja tidak hanya diukur dengan capaian materi, melainkan juga ditentukan oleh prestasi kerja, yang pada gilirannya menjadikan seseorang mencapai kedudukan tinggi dalam organisasi dan mendapat status sosial dalam masyarakat.

Sampai di sini bisa dipahami bila dikatakan, wanita karir, di samping bekerja untuk mendapatkan upah atau gaji, juga untuk memperoleh prestasi tinggi menurut ketetapan penyelesaian suatu pekerjaan. Dalam konteks ini, wanita karir mengetahui kapan dan bagaimana sebuah pekerjaan harus diselesaikan dengan baik. Selain itu, ia juga mampu

${ }^{12}$ Peter Salim dan Yeni Salim, Kamus Besar Bahasa Indonesia Kontemporer (Jakarta: English Press, 1991), 1125 .

${ }^{13}$ Wanita pekerja sendiri adalah mereka yang berkarya dan hasil karyanya itu ia mendapat imbalan uang. Ciri utama dari wanita pekerja ini adalah penekanannya pada imbalan yang diberikan. Artinya, pekerjaan wanita pekerja tidak harus ikut kepada orang lain, melainkan bisa juga bekerja mandiri, sepanjang apa yang dilakukannya itu menghasilkan uang. Karena itu, wanita pekerja bisa lebih tinggi atau rendah kedudukannya dari wanita karir. Sementara TKW adalah wanita yang bisa melakukan pekerjaan di dalam atau di luar hubungan kerja guna menghasilkan barang atau jasa dalam rangka memenuhi kebutuhan masyarakat. Ciri utama dari wanita ini adalah kemampuannya dalam melakukan pekerjaan, memiliki kedudukan dan penghasilan tinggi, sekaligus tidak identik dengan pembantu rumah tangga, dokter, para ahli dan sejenisnya.Omas Ihrami, "Wanita Bekerja dan Masalahmasalahnya," dalam Toety Herarty Nurhdi dan Aida Fitalaya s. Hubeis (ed), Dinamika Wanita Indonesia: multidimensional (Jakarta: Pusat Pengembangan Sumber Daya Wanita, 1990), 38.

${ }^{14}$ E. Kristi Poerwandari, “Aspirasi Perempuan dan Aktualisasinya” dalam T.O Ihromi (Penyunting), Kajian Wanita dalam Pembangunan Jakarta (Jakarta: Yayasan Obor Indonesia, 1995), 331. 
mengontrol pekerjaan dan ingkungan tempat kerjanya sehingga membuat pekerjaannya lebih efisien dan teratur.

\section{Klasifikasi Wanita Karir}

Dari sisi keterikatannya, wanita karir bisa dikelompokan kepada dua bagian, yaitu: ${ }^{15}$ pertama, wanita karir yang tidak terikat dengan tali perkawinan, yakni wanita karir yang belum menikah atau wanita yang pernah menikah tetapi telah bercerai. Wanita karir semacam ini bisa bekerja dengan bebas. Kedua, wanita karir yang terikat dengan tali perkawinan, yaitu wanita karir yang telah melangsungkan pernikahan. Wanita karir golongan ini tidak bebas bekerja melainkan terikat oleh berbagai hal, termsuk hak dan kewajiban sebagai isteri. Dalam tulisan ini, wanita yang dibahas adalah wanita karir tipe kedua.

Dalam karir yang bersifat long-run atau fulltime, wanita karir berbeda sikap dalam menjalani pekerjaaanya, yaitu:16 Pertama, wanita yang menempuh karir secara terinterupsi, yani dalam jangka waktu tertentu atau untuk sementara waktu ia berhenti dari profesi yang ditekuni disebabkan ada tugas yang lainnya. Kedua, wanita karir menempuh pola double track, yaitu kedua tugas (publik dan domestik) dijalani secara bersamaan. Ketiga, wanita karir menempuh pola stabil, yakni memprioritaskan pekerjaan atau karirnya dengan meninggalkan atau menomor-duakan tugas lainnya, baik yang domestik maupun publik. Kelompok yang terakhir ini menekuni karir secara total yang dalam tingkat tertentu berefek negatif bagi keluarga. Misalnya, meninggalkan rumah karena sibuk bekerja bisa berpotensi merusak keharmonisan rumah tangga, meski keharmonisan itu sendiri tidak hanya menjadi tanggung jawab istri. Lain halnya ketika wanita yang berkarir itu masih mempunyai komitmen yang sama tingginya antara pekerjaan dan rumahtangga. Seperti di Indonesia, di mana banyak diantara wanita yang berkarir masih mengutamakan keluarga dibandingkan pekerjaan. ${ }^{17}$

\section{Alasan Wanita Karir}

Fenomena wanita karir muncul dan tumbuh tidak berada di ruang hampa. Terdapat banyak faktor yang mendorong kaum hawa beralih menjadi wanita karir, misalnya; seorang wanita akan terjun di dunia kerja karena didorong oleh faktor pendidikan, di mana pendidikan bisa melahirkan wanita ahli dalam berbagai bidang, yang pada

${ }^{15}$ Lihat Bauna'i, "Wanita Karir dalam Perspektif Hukum Islam,” KARSA, Vol. 11 (Mei, 2001): 99.

${ }^{16}$ E. Kristi Poerwandari, "Aspirasi Perempuan dan Aktualisasinya”, 340.

${ }^{17}$ Juwairiah Dahlan, Peranan Wanita dalam Islam: Studi tentang Wanita karier dan Pendidikan Anak (Yogyakarta: Disertasi IAIN Sunan Kalijogo, Tidak diterbitkan, 2000), 403-405. 


\section{Afif Muamar}

gilirannya mampu meniti karir dalam bidang tersebut; faktor keterpaksaan kondisi dan kebutuhan; faktor kemandirian ekonomi, seperti agar tidak bergantung pada suami; motif mencari kekayaan; motif mengisi waktu luang atau kesenangan; dan motivasi untuk mengembangkan bakat. ${ }^{18}$ Artinya, wanita memiliki berbagai alasan ketika hendak memutuskan untuk bekerja di luar rumah.

Secara simplistik, terdapat tiga alasan mengapa wanita memilih bekerja di luar rumah, yaitu: ${ }^{19}$ pertama, alasan kebutuhan ekonomi (financial). Hal ini terkait dengan kebutuhan rumah tangga yang begitu besar dan mendesak yang memaksa suami dan istri bekerja agar dapat memenuhi kebutuhan sehari-hari. Dalam kondisi ini istri tidak mempunyai pilihan lain kecuali ikut mencari pekerjaan di luar rumah.

Kedua, kebutuhan sosial-relasional, yakni alasan beberapa wanita yang tetap memilih bekerja karena mempunyai kebutuhan sosial-relasional yang tinggi, yang kemudian merek dapatkan di tempat kerja mereka. Faktor ini terkait dengan diri wanita sendiri yang menyimpan hasrat akan terpenuhinya kebutuhan pengakuan (status) dan identitas sosial yang diperoleh melalui komunitas kerja. Karena itu, bagi wanita karir semacam ini, bergaul dengan rekan-rekan di kantor misalnya dipandang sebagai dunia yang lebih menyenangkan dari pada hanya tinggal di rumah. Selain faktor diri, faktor psikologis dan keadaan internal dalam keluarga juga bisa mempengaruhi seseorang untuk tetap bekerja di luar rumah.

Ketiga, kebutuhan aktualisasi diri, di mana wanita bekerja untuk mengaktualisasikan dirinya, berkarya, mengekspresikan dan mengembangkan diri dan orang lain, membagikan ilmu dan pengalaman, menemukan dan menghasilkan sesuatu, serta mendapatkan penghargaan atau prestasi. Kini, kebutuhan akan aktualisasi diri melalui karir ini diyakini merupakan salah satu pilihan yang banyak diambil oleh para wanita, terutama dengan makin terbukanya kesempatan untuk meraih jenjang karir yang lebih tinggi.

Bagi wanita yang sebelum menikah sudah bekerja karena dilandasi oleh kebutuhan aktualisasi diri yang tinggi, cenderung akan kembali bekerja setelah menikah dan mempunyai anak. Mereka merasa bekerja adalah hal yang sangat bermanfaat untuk memenuhi kebutuhan aktualisasi diri, membangun kebanggaan diri, dan juga mendapatkan kemandirian secara finansial. Sebuah studi tentang kepuasan hidup wanita bekerja menunjukkan bahwa wanita yang bekerja memiliki tingkat kepuasan hidup

${ }^{18}$ Huzaemah T. Yanggo, Fiqih Perempuan Kontemporer (Yogyakarta: Almawardiprima, 2001), 94.

${ }^{19}$ Uraian lengkap tentang alasan-alasan ini bisa dilihat dalam Journal of Marriage and the Family atau http://www.ibubekerja.info/tag/ibu-bekerja/. 
sedikit lebih tinggi dibandingkan dengan wanita yang tidak bekerja, meskipun ada beberapa faktor lain yang ikut menentukan. Selain itu, hasil penelitian yang dimuat dalam Journal of Marriage and the Family tentang ukuran kebahagiaan hidup wanita yang sudah menikah, ditinjau dari tiga kategori: wanita bekerja, wanita pernah bekerja, dan wanita yang belum pernah bekerja, disimpulkan bahwa bagi istri bekerja, kebahagiaan perkawinan tetap menjadi prioritas utama dibandingkan dengan kepuasan kerja. Ini berarti, meskipun aktualisasi diri telah mendorong para perempuan untuk bekerja di luar rumah, tapi tidak menyurutkan keinginan mereka untuk menempatkan kebahagiaan keluarga sebagai hal yang paling utama.

\section{Kepemimpinan Rumah Tangga dan Wanita Karir}

Konsep kepemimpinan dalam rumah tangga menjadi salah satu isu penting dalam wacana gender. Selain merupakan tema yang hingga kini masih diperdebatkan, konsep kepemimpinan rumah tangga juga sering dijadikan pijakan bagi pola hubungan antara suami dan isteri. Sebagian feminis muslim menggugat faham kemutlakan kepemimpinan suami dalam rumahtangga, karena dinilai bertentangan dengan konsep kesetaraan pria dan wanita. Konsep kepemimpinan dalam rumah tangga sendiri menjadi kontroversial ketika terdapat pemahaman terhadap firman Allah SWT dalam Surat An-Nisa' ayat:34, yang artinya:

Artinya: "Kaum laki-laki adalah pemimpin bagi kaum perempuan, oleh karena Allah telah melebihkan sebagian mereka (laki-laki) atas sebagian yang lain (wanita) dan karena mereka telah menafkahkan sebagian dari harta mereka". 20

Bagi pemikir normatif ayat tersebut berbicara tentang superioritas laki-laki atas perempuan dengan menempatkan laki-laki sebagai pemimpin rumah tangga dan perempuan sebagai pihak yang dipimpin. Kesimpulan ini di dasarkan pada lafaz qawwamun yang diartikan pemimpin serta potongan ayat bima faddalallah ba'duhum ala ba'din dan wabima anfaqu min amwa lihim. Dari sini didapat uda poin penting, yaitu: pertama, laki-laki secara potensial memiliki kelebihan atas perempuan. Kedua, dengan kelebihannya, laki-laki mempunyai hak dan tanggung jawab atas kehidupan keluarganya, isteri, dan anak. ${ }^{21}$ Konekuensinya, isteri, mau tidak mau, harus taat pada suami, termasuk

\footnotetext{
${ }^{20}$ Departemen Agama, Al-Qur'an dan Terjemahnya, 123.

${ }^{21}$ Tokoh yang termasuk kelompok normatif misalnya Muhammad Ali ash-Shabuni dan Imam Baidhawi. Menurut ash-Shabuni, qawwamun berarti pemimpin karena dua alasan, pertama, laki-laki memiliki kelebihan akal dibanding perempuan. Kedua, laki-laki yang memberi nafkah keluarganya. Konsekuensinya, perempuan harus taat kepada Allah dan suaminya, baik di rumah maupun di luar rumah. Jika isteri nusyuz, maka suami berhak memberikan teguran dan pengarahan bahkan pukulan demi mendidik isteri dan menjaga nama baik keluarga. 
dalam hal pekerjaan. Seumpama suaminya melarangnya bekerja, maka ia harus menaatinya.

Persoalannya sekarang apakah benar laki-laki pemimpin bagi perempuan dan harus ditaati secara mutlak? Tampaknya, pemahaman yang mengatakan bahwa suami memiliki peran mutlak sebagai pemimpin bagi wanita, karenaya wanita harus menaatinya, cenderung mengabaikan konteks historis ayat. Padahal, ayat itu seharusnya dipahami secara kontekstual. Surat al-Nisa' ayat 34 adalah ayat kontekstual, yang karenanya tidak bisa dipahami lepas dari konteks sosial pada waktu ayat itu diturunkan. ${ }^{22}$ Dari pembacaan kontekstual didapatkan bahwa keunggulan pria bukanlah keunggulan jenis kelamin, tetapi keunggulan fungsional, karena pria mencari nafkah dan membelanjakan hartanya untuk wanita (istri). Fungsi sosial yang diemban pria seimbang dengan wanita yang melaksanakan tugas-tugas domestik dalam rumahtangga. Karena itu, ungkapan "Kaum laki-laki adalah pemimpin bagi kaum perempuan" bukanlah pernyataan normatif tetapi kontekstual.

Selain itu, makna "qawwamun" dalam ayat tersebut tidak harus bermakna pemimpin, melainkan bisa juga penopang atau penguat bagi isteri, sehingga laki-laki bukan sosok penguasa yang menguasai dan mendominasi, melainkan sebagai pendukung bagi pasangannya. Karena itu, menempatkan perempuan di bawah dominasi laki-laki dalam segala urusan merupakan pendirian kelelakian yang melampaui batas. ${ }^{23}$ Dan yang lebih penting lagi, ayat tersebut tidak menentukan relasi laki-laki dan perempuan secara absolut dan tidak bergantung. Sebaliknya, status laki-laki maupun perempuan bergantung pada tindakan manusia (sesuai dengan kekayaan yang dinafkahkan untuk yang lain) dan bergantung pada tindakan Tuhan (yaitu, dengan kelebihan yang dianugerahkan Tuhan pada seseorang di atas yang lain). Hal ini selaras dengan ayat lain yang menunjukan bahwa fadl (keutamaa), baik yang berkaitan dengan pahala atau anugerah Tuhan, bisa diperoleh oleh siapa pun. Otoritas yang diberikan kepada laki-laki bukan karena dia laki-laki, tapi karena waktu itu, laki-laki yang menafkahi perempuan.

Menurut ash-Shabuni, kedudukan suami bagi isterinya sama dengan kedudukan pemimpin bagi rakyatnya. Sementara bagi Baidhawi, laki-laki menjadi karena, pertama, laki-laki memiliki kelebihan khusus dari Allah (kelebihan tanpa usaha) berupa kelebihan akal pikiran. Kedua, kelebihan yang diusahakan (kasbi), yaitu laki-laki diposisikan sebagai pihak yang bertanggung jawab atas kehidupan rumah tangga. Oleh karena itu, seorang isteri harus taat kepada Allah dan menegakkan hak-hak suaminya. Bagi Baidhowi, suami pada gilirannya berhak mendidik isterinya dan mencegahnya keluar rumah, berhak atas seluruh hartanya dan isteri tidak bisa membelanjakan harta tersebut tanpa izin suaminya, serta kewajiban menafkahi isterinya. Aksin Wijaya, Menggugat Otentisitas Wahyu Tuhan: Kritik Atas Nalar Tafsir Gender (Yogyakarta: Safiria Insania Press, 2004), 176.

22 Asghar Ali Engineer, Hak-hak Perempuan dalam Islam, Terj. Wajdi dan Cici Farkha Assegaf (Yogyakarta: Yayasan Bintang Budaya, 1994), 61.

${ }^{23}$ Masdar F. Mas'udi, Islam dan Hak-hak Reproduksi Perempuan, 67-68. 


\section{Afif Muamar}

Namun, apabila perempuan memiliki tanggung jawab yang sama dengan laki-laki, otoritas harus dibagi secara adil di antara keduanya. ${ }^{24}$

Dari pembacaan seperti ini bisa didapatkan bahwa Islam tidak menilai laki-laki lebih tinggi dari perempuan. Keduanya setara dan seharusnya saling mendukung dan melengkapi. Dalam konteks wanita karir, tidak perlu ada diskriminasi dalam memberikan kesempatan memperoleh pendidikan agar dalam mengarungi kehidupannya wanita dapat serasi mengimbangi pria terutama pasangan hidupnya. Dengan pendidikan wanita diharapkan dapat memperoleh pekerjaan yang layak sesuai dengan kemampuan dan kodratnya, sehingga hidupnya produktif, tidak stress atau menjadi penghayal karena terlalu banyak waktu luang yang ia lalui sehingga menimbulkan kejenuhan dan melahirkan sikap-sikap negatif yang merugikan orang-orang yang ada di sekitarnya. Karena itu, bisa dipahami bila al-Hatimi menyatakan bahwa wanita boleh bekerja dan menduduki jabatan strategis di wilayah publik dengan catatan tetap tunduk pada ajaran syari'at, serta tetap memprioritaskan peran utamanya sebagai ibu rumahtangga. Hal ini didasarkan pada fakta historis bahwa wanita di zaman Nabi SAW ikut berpartisipasi dalam urusan publik, seperti dalam peperangan. ${ }^{25}$

\section{Persamaan Laki-Laki dan Perempuan dengan Wanita Karir}

Islam adalah agama yang membawa nilai-nilai kesetaraan gender. Dalam ayat-ayat al-Qur'an ditegaskan bahwa laki-laki dan perempuan mempunyai tanggung jawab yang sama di hari pembalasan. ${ }^{26}$ Laki-laki dan perempuan diciptakan dari jenis yang sama (nafsin wahidah). ${ }^{27}$ Kemuliaan laki-laki dan perempuan sama dilihat dari prestasinya. ${ }^{28}$ Serta sebagai suami dan istri, laki-laki dan perempuan mempunyai kedudukan yang sederajat. $^{29}$ Artinya, laki-laki dan perempuan sama-sama sebagai hamba, sama-sama sebagai khalifah di bumi, sama-sama menerima perjanjian primordial, adam dan hawa sama-sama terlibat secara aktif dalam drama kosmos, serta laki-laki dan perempuan sama-sama berpotensi untuk meraih prestasi. ${ }^{30}$ Lebih tegas lagi misalnya, Khoiruddin Nasution menghimpun sejumlah nash yang berbicara tentang kemitrasejajaran perempuan dan laki-laki yang dapat dikelompokkan menjadi delapan,31 yakni: (1)

${ }^{24}$ Khaled M. Abou el-Fadl, Selamatkan Islam dari Muslim Puritan, terj. Helmi Mustofa, (Jakarta: Serambi, 2006), 320-321.

${ }^{25}$ Moenawar Khalil, Nilai Wanita (Solo: Ramadhani, 1989), 81.

${ }^{26}$ Al-An'am (6): 164, ayat yang senada al-Mu'min (40): 17, al-Muddatsir (74): 78.

27 An-Nisa' (4): 1.

${ }^{28}$ Ali 'Imran (3): 195, ayat yang senada an-Nahl (16): 97, al-Hujurat (49): 14.

${ }^{29}$ An-Nisa' (4): 32, ayat yang senada an-Nisa' (4): 35.

${ }^{30}$ Nasarudin Umar, Argumen Kesetaraan Gender: Perspektif Al-Qur'an (Jakarta: Paramadina, 1999), 247-

${ }^{31}$ Khoiruddin Nasution, Fazlur Rahman tentang Wanita (Yogyakarta: Tazzafa \& ACAdeMIA, 2002), 22. 
statemen umum tentang kesetaraan perempuan dan laki-laki, ${ }^{32}$ (2) kesetaraan asal usul,33 (3) kesetaraan amal dan ganjarannya, ${ }^{34}$ (4) kesejajaran untuk saling kasih dan mencintai, ${ }^{35}$ (5) keadilan dan persamaan, ${ }^{36}$ (6) kesejajaran dalam jaminan sosial, ${ }^{37}$ (7) saling tolong-menolong, ${ }^{38}$ (8) kesejajaran dalm hal kesempatan mendapat pendidikan. ${ }^{39}$

Al-Qur'an sendiri mengatakan bahwa pahala setiap orang yang beramal-laki-laki maupun perempuan, besar kecil, tua muda-sepanjang dirinya cakap hukum (memenuhi persyaratan syar'i), maka ia berhak mendapatkan pahala dari hasil perbuatannya. Artinya, tidak ada pembedaan reward yang akan diterima oleh seorang pelaku kebajikan hanya karena perbedaan jenis kelamin ataupun umur. Sebagaimana diterangkan dalam Al-Qur'an surat An-Nahl ayat 97:

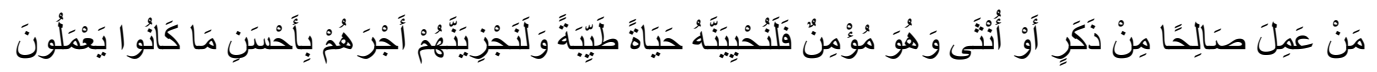

Artinya: "Barangsiapa yang mengerjakan amal saleh, baik laki-laki maupun perempuan dalam keadaan beriman, maka sesungguhnya akan Kami berikan kepadanya kehidupan yang baik dan sesungguhnya akan Kami beri balasan kepada mereka dengan pahala yang lebih baik dari apa yang telah mereka kerjakan". 40

Dari ayat di atas serta berbagai ayat Al-Qur'an yang menjelaskan ajaran persamaan laki-laki dan perempuan dalam Islam, bisa ditarik benang merah bahwa laki-laki dan perempuan memiliki hak dan kewajiban yang sama, termasuk dalam hal bekerja tidak ada diskriminasi bagi wanita dalam hal meniti karir. Hal ini ditegaskan lebih lanjut oleh Lailiy Muthmainnah dalam melihat realitas objektif, sehingga muncul rekonstruksi tafsir yang lebih demokratis dan kontekstual, yang berarti agama benar-benar menjadi ajaran yang sangat respek terhadap berbagai persoalan gender. ${ }^{41}$ Oleh karena itu, titik perbedaan antara laki-laki dan perempuan hanya terletak pada jenis pekerjaan yang akan dibedakan menurut kredibilitas, skill dan kompetensi masing-masing. Artinya, pembedaan hanya terletak pada peran yang bersifat kodrati. Oleh kerananya, hikmah diciptakan dua pasang manusia yang berbeda, bukan hanya pada bentuk dan postur tubuh serta jenis

${ }^{32}$ Al-Baqarah (2): 187, 228.

33 An-Nisa' (4): 1, Al-Hujurat (49): 13.

${ }^{34}$ Ali 'Imran (3): 195, an-Nisa' (4): 32, at-Taubah (9): 72, al-Ahzab (33): 35-36, al-Mu'min (40): 40, al-Fath (48): 5, al-Hujurat (49): 13, al-Hadid (57): 12, dan al-Mumtahanah (60): 12.

${ }^{35}$ Al-Isra' (17): 24, ar-Rum (30): 21, al-Ahqaf (46): 15 dan Al-Baqarah (2): 187.

${ }^{36}$ Al-Baqarah (2): 228 dan an-Nahl (67): 97.

${ }^{37}$ Al-Baqarah (2): 177.

${ }^{38}$ At-Taubah (9): 71, al-Maidah (5): 2.

${ }^{39}$ Al-Mujadalah (58): 11, Az-Zumar (39): 9.

40 An-Nahl (16): 97.

${ }^{41}$ Lailiy Muthmainnah, "Membincang Kesetaraan Gender dalam Islam (Sebuah Perdebatan dalam Wacana Hermeneutik)”, Jurnal Filsafat, Vol. 40, No. 2 (Agustus, 2006): 213. 


\section{Afif Muamar}

kelaminnya saja, akan tetapi juga pada emosional dan komposisi kimia dalam tubuh. Hal ini membawa kesan kepada perbedaan dalam tugas, kewajiban dan hak. Dan hal ini sangatlah wajar dan sangat logis, karena bukan sesuatu yang mendiskriminasikan sehingga merendahkan wanita tetapi merupakan bentuk sebuah keseimbangan hidup, seperti anggota tubuh manusia yang berbeda-beda tapi menuju kepada persatuan dan saling melengkapi. ${ }^{42}$

Bukti bahwa tidak ada pembedaan antara laki-laki dan perempuan dalam bekerja adalah kisah hidup salah satu ummu al-ummahat umat Islam, yakni, Khadijah binti Khuwailid RA. Khadijah adalah sosok manusia yang gigih dan mampu mengantarkan kesuksesan Nabi Muhammad SAW. Tentunya sedikit banyak harta Khadijah didermakan untuk kepentingan umat saat itu. Segala keperluan peperangan nabi selalu dilayani oleh Khadijah. Dan hal semacam ini tidak dilarang oleh nabi. Karena itu, aneh bila kini wanita karir dipersoalkan sedangkan telah jelas Khadijah pun juga berdagang dan berbisnis. Padahal Nabi sendiri tidak melarangnya. Selain itu, Al-Qur'an tidak mencegah perempuan ke luar rumah dan juga tidak menyebutkan bahwa mereka harus ditemani oleh keluarga dekat laki-laki ketika mereka bepergian ke luar rumah. Pada masa Nabi juga perempuan berpartisipasi dalam peperangan yang secara ketat merupakan wilayah yang didominasi oleh laki-laki. Diriwayatkan dalam Sahih Bukhari, bahwa perempuan muslim secara aktif membantu mereka yang terluka di saat perang Uhud berkecamuk. Termasuk di dalam perempuan ini adalah isteri nabi sendiri. ${ }^{43}$

Secara umum, Islam sangat menghormati kewajiban wanita yang sangat sesuai dengan fitrah kewanitaannya. Sebagaimana disinggung di atas, wanita mempunyai kesempatan bekerja di sektor luar rumah, namun pekerjaannya juga harus sesuai dengan kodrat kewanitannya. Islam tidak memperbolehkan wanita bekerja dan atas pekerjaannya itu menjadikannya terhina. Wanita bisa bekerja di luar rumah, selama pekerjaan itu sesuai dengan tabi'at, spesialisasi dan kemampuannya, serta tidak merusak derajat kewanitannya. Oleh karenanya, Islam mensyariatkan pula bagi wanita untuk bekerja di luar rumahnya, atau pada saat masyarakat itu sendiri sangat membutuhkan

${ }^{42}$ Nurazidawati Mohamad Arsad, et.al., "Peranan Bapak dalam Mewujudkan Keadilan Gender dalam Rumah Tangga: Islam dan Sains”, Marwah: Jurnal Perempuan, Agama dan Jender, Vol. 16, No. 2 (2017): 173.

${ }^{43}$ Kitab Fath Khaibar karya Abu Daud menyatakan bahwa ketika perang Kahibar terjadi, setengah lusin perempuan Madinah ikut tentara Islam. Nabi tidak mengetahui hal tersebut, dan ketika diberitahu nabi pun marah dan berkata: "Mengapa mereka ikut?" para wanita ini kemudian menimpali bahwa mereka membawa obat-obatan, mereka akan merawat pejuang Islam yang terluka, mencabut panah dari tubuh tentara, dan mengatur makanan mereka. Mendengar hal demikian, nabi pun mengijinkan mereka untuk menemni tentara, dan ketika Khaibar ditaklukkan, nabi juga membagi ghanimah kepada para wanita tersebut. Lihat Heroic Deeds of Muslim Women, Islamabad, 1990, hlm. 2-3. 


\section{Afif Muamar}

pekerjaannya. Dan kebutuhan untuk bekerja di sini bukan hanya kebutuhan yang terbatas pada penghasilan materi saja, namun juga terkadang telah menjadi kebutuhan psikisnya, seperti kebutuhan guru wanita yang belum kawin dalam bidang-bidang tertentu, atau guru wanita yang sudah kawin namun belum memiliki keturunan, atau adanya perasaan hampa yang berlarut-larut atau adanya perasaan bosan yang dapat menjadikan stress. ${ }^{44}$ Karena itu, kebolehan wanita karir tidak berarti wanita bebas bekerja sebebas-bebasnya, melainkan ia juga harus memperhatikan kodrat kewanitaannya.

\section{Batasan Wanita Karir}

Telah disebutkan bahwa wanita karir dalam Islam diperbolehkan. Masalahnya, apakah semua jenis dan motif wanita yang hendak meniti karir di luar rumah diperbolehkan? Persoalan ini tidak mudah dijawab karena berbicara wanita karir kaitannya dengan perkawinan dan keluarga, tidak hanya soal boleh-tidak boleh, lebih dari itu, ia menyangkut persoalan psikologis dan kepentingan dari masing-masing anggota keluarga, seperti isteri, suami dan anak. Meski demikian, barangkali bisa disebut beberapa pendapat para sarjana Muslim sebagai pintu masuk untuk mengurai permasalahan ini.

Menurut Yusuf al-Qardhawi tidak ada larangan bagi wanita bekerja atau melakukan aktifitas di luar rumah untuk mengembangkan karirnya asal pekerjaan domestik tidak ditinggalkan, seperti memelihara rumah tangga, hamil, melahirkan, mendidik anak dan menjadi tempat berteduhnya suami guna mendapatkan ketenangan ketika suami datang dari kerja dan kelelahan setelah bersusah payah mencari nafkah. Bahkan wanita yang bekerja di luar rumah kadang-kadang dituntut dengan ketentuan sunnah dan wajib apabila ia membutuhkannya, dengan catatan pekerjaan itu sesuai dengan tabi'at spesialisasi dan kemampuan serta tidak merusak derajat kewanitaannya. ${ }^{45}$ Seperti bekerja untuk mengobati orang sakit, berniaga untuk keperluan keluarga seperti yang dilakukan Khadijah istri Rasulullah. Selain itu, tidak ada larangan wanita bekerja dan berkarir apabila mampu, dan tetap mendapatkan nafkah dari suaminya dalam tanggunagannya karena nafkah merupakan beban finansial yang ditanggung oleh suami.

Sementara itu, Engineer mengatakan nafkah merupakan tanggung jawab suami kepada istrinya, meskipun istri memiliki kekayaan dan pendapatan. Nafkah kepada istri adalah konsekuensi adanya ikatan perkawinan yang sah. ${ }^{46}$ Dengan prinsip kemitra

${ }^{44}$ Yusuf al-Qardhawi, Ruang Lingkup Aktivitas Wanita Muslimah, terj. Moh. Suri Sudahri dan Entin Rani'ah Ramelan (Jakarta: PUSTAKA KAUTSAR, 1996), 224.

${ }^{45}$ Yusuf al-Qardawi, Fatwa-fatwa Kontemporer, terj. As'ad Yasin (Jakarta: Gema Insani Press, 1996), 422.

${ }^{46}$ Ashar Ali Engineer, Hak-hak Perempuan dalam Islam, terj. Farid wajidi, (Bandung: LSPPA, 1994), 164. 


\section{Afif Muamar}

sejajaran antara suami istri yang digunakan oleh al- al-Qaradowi, berarti tidak ada larangan bagi istri untuk membantu suami dalam mencari nafkah dengan izin suaminya, tidak menggangu pelaksanaan kewajibannya sebagai seorang ibu rumah tangga dan tidak mendatangkan suatu yang negatif dari diri sendiri, keluarga, masyarakat dan agamanya.

Merujuk pada fakta historis Islam, Quraish Shihab menegaskan bahwa tidak berlebihan jiak dikatakan bahwa Islam membenarkan mereka aktif dalam berbagai aktifitas. Menurutnya, para wanita boleh bekerja dalam berbagai bidang, di dalam maupun di luar rumah, secara mandiri ataupun bersama orang lain, dengan lembaga pemerintah maupun swasta, selama pekerjaan tersebut dilakukan dalam suasana terhormat, sopan, serta selama mereka dapat memelihara agamanya, serta dapat pula menghindari dampak-dampak negatif dari pekerjaan tersebut terhadap diri dan lingkungannya. Singkatnya, wanita memiliki hak untuk bekerja dan berkarir selama pekerjaan tersebut membutuhkannya dan atau selama mereka membutuhkan pekerjaan tersebut. $^{47}$

Argumentasi berbeda diungkapkan seorang Kyai yang juga dikenal sebagai feminis, Husein Muhammad. Menurutnya, sesungguhnya Islam tidak pernah menekankan wanita dalam bidang pekerjaan, baik di dalam maupun di luar rumah. Islam memandang perempuan bukan sebagai mahluk domestik (mahluk rumahan) yang tidak diperkenankan merambah wilayah publik (umum). Pria dan wanita sama-sama berhak berkiprah di segala bidang, baik sosial, pendidikan, politk maupun lainya, termasuk di dalamnya hak untuk berkarir dalam bidang ekonomi. Pria dan wanita mempunya hak yang sama untuk bekerja, sekaligus menikmati hasil jerih payahnya.

Barangkali persoalan akan timbul ketika seorang istri yang bekerja itu tidak mendapat restu suaminya. Hal ini seringkali dianggap melanggar agama, karena dianggap menentang keputusan suami. Bagi Husein Muhammad, cara pandang seperti ini keliru dan tidak bisa serta merta dianggap melanggar agama. Harus dilihat terlebih dulu apa yang melatari suami tidak merestuinya. Sebab alasan suami tidak mengijinkan istri bekerja biasanya lebih karena alasan pribadi bukan karena alsan agama. Terlebih lagi, jika disimak lebih dalam, menurutnya, banyak ulama yang berpandangan bahwa suami tidak berhak untuk melarang istri bekerja mencari nafkah, apabila nyata-nyata suami tidak mampu bekerja mencari nafkah, baik karena sakit, miskin atau karena yang lain. Jadi

${ }^{47}$ M. Quraish Shihab, Membumikan Al-Qur'an (Bandung: Mizan, 1994), 275. 
Afif Muamar

kewajiaban seorang suami untuk mencari nafkah tidak menghalang istri untuk bekerja di luar rumah atau berkarir juga mencari nafkah.

\section{KESIMPULAN}

Dari uraian di atas, bisa disimpulkan beberapa hal, yaitu: pertama, secara psikologis, keberadaan wanita karir bisa mempengaruhi tatanan perkawinan dan keluarga, yang apabila tidak diatur dengan baik bukan mustahil akan berakibat pada disharmonisasi perkawinan dan keluarga. Kedua, dalam Islam tidak ada yang berhak melarang wanita untuk bekerja di luar rumah, termasuk suami sekalipun. Hal ini terkait dengan doktrin Islam sendiri yang sebenarnya tidak pernah membedakan antara laki-laki dan perempuan dari sisi jenis kelamin. Selain itu, Islam juga menghargai persamaan hak bagi laki-laki dan perempuan. Hal ini dipertegas oleh fakta historis pada masa Nabi, di mana wanita juda berparisipasi di sektor public. Ketiga, dalam Islam, konsep wanita karir tidak berarti seorang isteri/ibu bebas bekerja menelantarkan nasib perkawinan dan keluarganya. Artinya, pekerjaan yang diambil oleh wanita yang hendak meniti karir di sektor public harus didasarkan pula atas kepentingan keluarga.References (example)

\section{DAFTAR PUSTAKA}

Al-Qardhawi, Yusuf. Fatwa-fatwa Kontemporer, terj. As'ad Yasin. Jakarta: Gema Insani Press, 1996.

Ruang Lingkup Aktivitas Wanita Muslimah, terj. Moh. Suri Sudahri dan Entin Rani'ah Ramelan. Jakarta: PUSTAKA KAUTSAR, 1996.

Arsad, Nurazidawati Mohamad, et.al. "Peranan Bapak dalam Mewujudkan Keadilan Gender dalam Rumah Tangga: Islam dan Sains", Marwah: Jurnal Perempuan, Agama dan Jender, Vol. 16, No. 2 (2017).

Bauna'i, “Wanita Karir dalam Perspektif Hukum Islam," KARSA, Vol. 11 (Mei, 2001).

Dahlan, Juwairiah. Peranan Wanita dalam Islam: Studi tentang Wanita Karir dan Pendidikan Anak. Yogyakarta: Disertasi IAIN Sunan Kalijogo, Tidak diterbitkan, 2000.

El-Fadl, Khaled M. Selamatkan Islam dari Muslim Puritan, terj. Helmi Mustofa, Jakarta: Serambi, 2006.

Engineer, Asghar Ali. Hak-hak Perempuan dalam Islam, Terj. Wajdi dan Cici Farkha Assegaf. Yogyakarta: Yayasan Bintang Budaya, 1994. 
Engineer, Asghar Ali. Islam dan Teologi Pembebasan, terj. Agung Prihantoro, cet. ke-1. Yogyakarta: Pustaka Pelajar, 1999.

Fakih, Mansour. "Fiqh Sebagai Paradigma Keadilan," dalam Noor Ahmad, et.al. Epistemologi Syara': Mencari Format Baru Fiqh Indonesia, cet. ke-1. Yogyakarta: Pustaka Pelajar, 2000.

Heroic Deeds of Muslim Women, Islamabad, 1990.

Ihromi, T.O. (Penyunting). Kajian Wanita dalam Pembangunan Jakarta. Jakarta: Yayasan Obor Indonesia, 1995.

Khalil, Moenawar. Nilai Wanita. Solo: Ramadhani, 1989.

Mas'udi, Masdar F. "Perempuan diantara Lembaran Kitab Kuning," dalam Mansour Fakih, et.al. Membincang Feminisme: Diskursus Gender Perspektif Islam. Surabaya: Risalah Gusti, 1996.

Masdar F. Mas'udi. Islam dan Hak Reproduksi Perempuan. Bandung: Mizan, 1997.

Mernissi, Fatima. Wanita di dalam Islam, terj. Yaziar Radianti. Bandung: Pustaka, 1994.

Muleono, Anton M. Kamus Besar Bahasa Indonesia, cet. II. Jakarta: Departemen Pendidikan dan Kebudayaan, 1989.

Muthmainnah, Lailiy. "Membincang Kesetaraan Gender dalam Islam (Sebuah Perdebatan dalam Wacana Hermeneutik)", Jurnal Filsafat, Vol. 40, No. 2 (Agustus, 2006).

Nasution, Khoiruddin. Fazlur Rahman tentang Wanita. Yogyakarta: Tazzafa \& ACAdeMIA, 2002.

Nazir, Moh. Metode Penelitian. Bandung: Ghalia Indonesia, 2003.

Puspitawati, Herien. "Persepsi Peran Gender terhadap Pekerjaan Domestik dan Publik Pada Mahasiswa IPB", Yin Yang: Jurnal Studi Gender dan Anak, Vol. 5, No. 1 (Juni, 2010).

Rahmat, Jalaludin. Metodologi Hukum. Jakarta: Fajar Agung, 1997.

Salim, Peter dan Yeni Salim, Kamus Besar Bahasa Indonesia Kontemporer. Jakarta: English Press, 1991.

Shihab, M. Quraish. Membumikan Al-Qur'an. Bandung: Mizan, 1994.

Sugiyono. Metode Penelitian Kuantitatif, Kualitatif dan R\&D. Bandung: Alfabeta, 2013.

Sukanto, Suerjono dan Sri Mamudji. Penelitian Hukum Normatif Suatu Tinjauan Singkat, Cet. 11. Jakarta: PT. Raja Grafindo Persada, 2009.

Toety Herarty Nurhdi dan Aida Fitalaya s. Hubeis (ed), Dinamika Wanita Indonesia: multidimensional. Jakarta: Pusat Pengembangan Sumber Daya Wanita, 1990. 
Umar, Nasarudin. Argumen Kesetaraan Gender: Perspektif Al-Qur'an. Jakarta: Paramadina, 1999.

Wijaya, Aksin. Menggugat Otentisitas Wahyu Tuhan: Kritik atas Nalar Tafsir Gender. Yogyakarta: Safiria Insania Press, 2004.

Yanggo, Huzaemah T. Fiqih Perempuan Kontemporer. Yogyakarta: Almawardiprima, 2001. 